\title{
International Law in Asia: A Bibliographic Survey -2018
}

\author{
Soyeon Moon
}

\section{Introduction}

This bibliography provides information on books, articles, notes, and other materials dealing with international law in Asia, broadly defined. Only English language publications that are newly published in 2018 or those that were previously published but had updated editions in 2018 are listed in this survey. Please refer to earlier editions of Asian Yearbook of International Law for earlier bibliographies.

Most, if not all, of the materials can be listed under multiple categories, but each item is listed under a single primary category. However, edited books may appear more than once if multiple chapters from the book are listed under different categories. Readers are advised to refer to all categories relevant to their research. The headings used in this year's bibliography are as follows:

1. General Theories and Asian Culture

2. Boundary Delimitation and Sovereignty

3. International Dispute Settlement

4. Arbitration

5. Development

6. Commercial Law

7. Economic and Business Law

8. Intellectual Property and Technology

9. Environmental Law

10. Human Rights

11. Migration and Refugees

12. International Humanitarian Law, Criminal Law, and Transnational Crime

13. Law of the Sea

14. Maritime Law

15. Watercourses

16. Air and Space

17. Miscellaneous 
Donna Brunero \& Stephanie Villalta Puig (eds.), life in Treaty Port China AND JAPAN (2018).

Alessandro Chechi, Non-State Actors and the Implementation of the World Heritage Convention in Asia: Achievements, Problems, and Prospects, 8(2) Asian Journal of International LAW 461-489 (2018).

Moeen H. Cheema, Two Steps Forward One Step Back: The Non-Linear Expansion of Judicial Power in Pakistan, 16(2) International Journal of Constitutional LAW 503-526 (2018).

Qi Chen, Governance, Social Control and Legal Reform in China: Community Sanctions and Measures (2018).

Tai-uk Chung et al. (eds.), On the Asian and European Origins of Legal and Political Systems: Views from Korea, Kazakhstan and France (2018).

Ralph Cossa \& Brad Glosserman, The Pivot is Dead, Long Live the (Indo-Asia-Pacific) Pivot, 2o(2) Comparative Connections: A Triannual E-Journal of Bilateral Relations in the Indo-Asia-Pacific 1-13 (2018).

Renato Cruz De Castro, The Obama Administration's Strategic Rebalancing to Asia: Quo Vadis in 2017?, 33(2) PACIFIC Focus 179-208 (2018).

Arnab Dey, Diseased Plantations: Law and the Political Economy of Health in Assam, 1860-1920, 52(2) Modern Asian Studies 645-682 (2018).

Hiroshi Fukurai, Fourth World Approaches to International Law (FWAIL) and Asia's Indigenous Struggles and Quests for Recognition Under International Law, 5(1) AsIAN Journal OF LAW AND Society 221-231 (2018).

Terence C. Halliday, Legal Freedoms: Struggle in the Theory of Legal Change in Asia, 5(1) Asian Journal of LAW AND Society 233-246 (2018).

Andrew Harding, Multi-level, Recursive Law and Development: Singapore's Legal Role in ASEAN, 5(2) Asian Journal of LAW ANd Society 251-269 (2018).

Herman Hidayat et al., Forests, Law and Customary Rights in Indonesia: Implications of a Decision of the Indonesian Constitutional Court in 2012, 59(3) AsIA PACIFIC VieWPOINT 293-308 (2018).

J.L. Kaul \& Anupam Jha (eds.), Shifting Horizons of Public International Law: A South Asian Perspective (2018).

Saloni Khanderia, The Hague Judgments Project: Assessing its Plausible Benefits for the Development of the Indian Private International Law, 44(3) CомmONWEALT H LAW BulLETIN 452-475 (2018).

Sung Won Kim, Eastphalia Revisited: The Potential Contribution of Eastphalia to Post-Westphalian Possibilities, 33(3) PACIFIC Focus 434-454 (2018).

Koesrianti, Book Review: History and Theory of International Law - From Community to Compliance? The Evolution of Monitoring Obligations in ASEAN by Simon Chesterman, 8(1) Asian Journal of International LaW 293-294 (2018). 
Teilee Kuong, Legal Assistance in the Japanese ODA: The Spark of a New Era, 5(2) AsIAN Journal OF LAW AND Society 271-287 (2018).

Katherine Lemons, Sharia Courts and Muslim Personal Law in India: Intersecting Legal Regimes, 52(3) LAW \& Society Review 6o3-629 (2018).

Jianhong Liu \& Setsuo Miyazawa (eds.), Crime and Justice in ContemPORARY JAPAN (2018).

Nengye Liu, Book Reviews: History and Theory of International Law - China, State Sovereignty and International Legal Order. By CHAN Phil C.W.-ERRATUM, 9(2) Asian Journal of International LaW 399 (2018).

Michael Loney, Comparing the Doctrine of Equivalents Across Asia, Managing InTELLECTUAL Property (2018).

Madeleine Martinek, Experimental Legislation in China Between Efficiency and Legality: The Delegated Legislative Power of the Shenzhen Special Economic Zone (2018).

Mark Massoud, The Futility of Law and Development:China and the Dangers of Exporting American Law, 5(1) Asian Journal of LAW ANd Society 213-215 (2018).

Hiromichi Matsuda, Book Reviews: History and Theory of International Law Globalization and Constitution: Tensions and Coordination with Supranational Legal Order by Yamada Satoshi, 8(2) Asian Journal of InTERnAtional LAW 490-491 (2018).

Alastair McClure, Sovereignty, Law, and the Politics of Forgiveness in Colonia India, 18581903, 38(3) Comparative Studies of South Asia, Africa, And the Middle EAST 385-401 (2018).

Evelyn Moser \& Anna Skripchenko, Russian NGOs and Their Struggle for Legitimacy in the Face of the Foreign Agents' Law: Surviving in SmallEcologies, 70(4) EU RO PE-As IA STUdies 591-614 (2018).

Seung Jin Oh, Historical Injustice and its Implications on International Law in East Asia, 33(3) PACific Focus 39o-413 (2018).

Si-Jin Oh, Historical Injustice in East Asia: A Case for Interspatial Law, 33(3) PACIFIC Focus 414-433 (2018).

Asif H. Qureshi, Contextualizing International Law in Northeast Asia (2018).

Siavash Rahbari, From Normative Pluralism to a Unified Legal System in Afghanistan?, 5(2) Asian Journal of LAW AND Society 289-314 (2018).

Saumya Saxena, 'Court'ing Hindu Nationalism: Law and the Rise of Modern Hindutva, 26(4) Contemporary South Asia 378-399 (2018).

Guo-Quan Seng, The Gender Politics of Confucian Family Law: Contracts, Credit, and Creole Chinese Bilateral Kinship in Dutch Colonial Java (1850s-1900), 60(2) Comparative Studies in Society And History 390-414 (2018).

Takao Suami et al. (eds.), Global Constitutionalism from European and East Asian Perspective (2018). 
Raeesa Vakil, Constitutionalizing Administrative Law in the Indian Supreme Court:

Natural Justice and Fundamental Rights, 16(2) International Journal of Constitutional LAW 475-502 (2018).

Dimitri Vanoverbeke et al. (eds.), Developing EU-Japan Relations in a Changing Regional Context: A Focus on Security, Law and Policies (2018).

Ingo Venzke, What if? Counterfactual (Hi)Stories of International Law, 8(2) Asian Journal OF INTERNATIONAL LAW 403-431 (2018).

Bijun $\mathrm{Xu}$, The Triple Invention: A Forgotten Memory in the Discourse of the Nineteenth Century's International Law, 11(2) Journal of EAST ASIA AND INTERNATIONAL LAW $375^{-376}$ (2018).

Monika Chansoria, China, Japan, and Senkaku Islands: Conflict in the East China Sea Amid an American Shadow (2018).

Anna Costa, The China-Japan Conflict Over the Senkaku/Diaoyu ISLANDS: USEFUL RIVALRY (2018).

Huiyun Feng \& Kai He (eds.), us-China Competition and the South China Sea Disputes (2018).

Seokwoo Lee \& Leonardo Bernard, South China Sea Arbitration and its Application to Dokdo, 8(1) Asian Journal of International LAW 24-35 (2018).

Laurent Mayali \& John Yoo, Resolution of Territorial Disputes in East Asia: The Case of Dokdo, 36(3) Berkeley Journal of Inte rnational LaW 504-550 (2018).

Kentaro Serita, The Territory of Japan: Its History and Legal Basis (Alex Meyer trans., 2018).

Farid Shafiyev, Resettling the Borderlands: State Relocations and Ethnic Conflict in the South Caucasus (2018).

Nianshen Song, Making Borders in Modern East Asia: The Tumen River Demarcation, 1881-1919 (2018).

Tim Summers, The Hong Kong Special Administrative Region at 20: Evaluating the Sino-British Joint Declaration, 7(1) Asian Education ANd Development STUdies 89-101 (2018).

\section{$3 \quad$ International Dispute Settlement}

Diane A. Desierto, Enforcement Options and Paths to Compliance:Disputants and Global Stakeholders in Philippines $v$. China, 8(1) Asian Journal of International LAW 64-75 (2018). 
Lan Ngoc Nguyen, The UNCLOS Dispute Settlement System: What Role Can it Play in Resolving Maritime Disputes in Asia?, 8(1) Asian Journal of International LAW 91-115 (2018).

Umar A. Oseni et al., The Feasibility of Online Dispute Resolution in the Islamic Banking Industry in Malaysia: An Empirical Legal Analysis, 6o(1) INTE RNATIONAL JOURNAL of LAW AND Manage MENT 34-54 (2018).

Julia Y. Yang, Lessons from the South China Sea Ruling: Med-ARB as the Recommended Dispute Resolution Method for Asia's Maritime Disputes Under UNCLOS, 19(3) Cardozo Journal of Conflict Resolution 783-8o8 (2018).

Gary F. Bell (ed.), The uncitral Model law and Asian Arbitration LAWS: IMPLEMENTATION AND COMPARISONS (2018).

Vijay K. Bhatia et al. (eds.), International Arbitration Discourse and Practices in Asia (2018).

Julien Chaisse \& Rahul Donde, The State of Investor-State Arbitration: A Reality Check of the Issues, Trends, and Directions in Asia-Pacific, 51(1) The International LAWYER 47-67 (2018).

Julien Chaisse \& Luke Nottage (eds.), International Investment Treaties and Arbitration Across Asia (2018).

Liz (Kyo-Hwa) Chung, International Arbitration in South Korea: A New Push Forward, 112 Proceedings of the American Society of International LaW Annual Meeting 98-10o (2018).

Yuka Fukunaga, International Arbitration and Japan: Stagnant, but Signs of Change?, 112 Proceedings of the American Society of International LaW AnNual MeEting 100-102 (2018).

David Hope, Making the Best of Arbitration, 26(1) Asia Pacific Law Review 1-13 (2018).

M.C.W. Pinto, Arbitration of the Philippine claim Against China, 8(1) As IAN JournaL of INTERNATIONAL LAW 1-11 (2018).

Anselmo Reyes \& Weixia Gu (eds.), The Developing World of Arbitration: A Comparative Study of Arbitration Reform in the Asia Pacific (2018).

Huawei Sun, Emerging Investment Treaty Arbitration Practice in China, 112 ProCeedings of the American Society of International Law Annual MeEting 103-105 (2018).

Ling Yang, Best International Arbitration Practice in Hong Kong, 112 Proceedings of the American Society of International LaW Annual Meeting 105-108 (2018). 
Julien Chaisse \& Jedrzej Gorski (eds.), The Belt and Road Initiative: LAW, ECONOMICS, AND Politics (2018).

Armand de Mestral et al. (eds.), Sustainable Development, International Aviation, and Treaty Implementation (2018).

Yong Deng, How China's Belt and Road is Reordering Asia, 39(4) Harvard InTERNATIONAL REVIEW 30-35 (2018).

Weixia Gu, China's Belt and Road Development and a New International Commercial Arbitration Initiative in Asia, 51(5) VANDERbilt Journal of TransNational LAW 1305-1352 (2018).

Maha S. Kamel, China's Belt and Road Initiative: Implications for the Middle East, 31(1) Cambridge Review of International Affairs 76-95 (2018).

$\mathrm{Pu}$ Niu \& Hendrik Wagenaar, The Limits of Authoritarian Rule: Policy Making and Deliberation in Urban Village Regeneration in China, 19(4) JAPANESE JOURNAL OF Political Science 678-693 (2018).

Jan Ott, Law and Development in Asia - Editor's Note to Special Issue, 5(2) Asian JoURNAL OF LAW AND SOCIETY 249-250 (2018).

Wenhua Shan et al. (eds.), Normative Readings of the Belt and Road Initiative: Road to New Paradigms (2018).

Poomintr Sooksripaisarnkit \& Sai Ramani Garimella (eds.), China's One Belt One Road Initiative and Private International laW (2018). Yaodong Yu \& Yen-Chiang Chang, The 'One Belt One Road' Initiative and its Impact on Shipping Law in China, 87 MARINe PoliCY 291-294 (2018).

\section{$6 \quad$ Commercial Law}

Julien Chaisse \& Luke Nottage (eds.), International Investment Treaties and Arbitration Across Asia (2018).

Holger Fleischer et al. (eds.), Issues and Challenges in Corporate and Capital Market Law: Germany and East Asia (2018).

Yuka Fukunaga, Abuse of Process Under International Law and Investment Arbitration, 33(1) Foreign Investment LAW Journal 181-211 (2018).

Umair Ghori, The International Investment Court System: The Way Forward for Asia?, 21 International Trade AND Business LAW RevieW 205-229 (2018).

Olly Jackson, Regulators will be Tougher on Antitrust Enforcement, INTERNATIONAL FinanCial LAW REview (2018).

Karry Lai, Chinese Businesses Feel the Bite of New Bribery Law, International Financial LaW REView (2018). 
Mel Marquis \& Jingyuan Ma, Confucian Bureaucracy and the Administrative Enforcement of Competition Law in East Asia, 43(1) North CARolina Journal of INTERNATIONAL LAW 1-71 (2018).

Hans Micklitz et al., Dissemination of Consumer Law and Policy in Africa, Asia, the Americas, and Australia, 41(4) Journal of Consumer Policy 303-307 (2018).

Ploykaew Porananond, Competition Law in the asean Countries: Regional Law and National Systems (2018).

Devi Lucy Y. Siadari \& Koki Arai, International Enforcement of ASEAN Competition Law, 9(5) Journal of European Competition Law \& Practice 328-335 (2018).

\section{Economic and Business Law}

Saidatul Aziz \& Salawati Basir, ASEAN Economic Community 2015: Restrictions on Malaysian Foreign Investment Law and Policy in Realizing ASEAN Comprehensive Investment Agreement (ACIA), 19(S3) International Journal of Business AND SOCIETY 414-425 (2018).

Julien Chaisse \& Luke Nottage (eds.), International Investment Treaties and Arbitration Across Asia (2018).

Salvador del Rey \& Robert J. Mignin (eds.), International labour and Employment Compliance Handbook (4th ed. 2018).

Mark Fenwick \& Stefan Wrbka, international Business LaW: Emerging Fields of REgulation (2018).

Pasha L. Hsieh, Against Populist Isolationism: New Asian Regionalism and Global South Powers in International Economic Law, 51(3) Cornell International LAw JournaL 683-729 (2018).

Eon Kyung Kim \& Taegil Kim, Historical Injustice in Asia and the Role of International Economic Law: How is Fair Trade for Implementation of a 'Level Playing Field' Realized?, 6(1) The Korean Journal of International and Comparative LAW 94-98 (2018).

Tuan Minh Le, Tax Trends and Tax Reforms in the Developing East Asia and Pacific Region, 9o(7) Tax Notes Inte Rnational 751-756 (2018).

Catherine Li, The EU's Proposal Regarding the Establishment of the Investment Court System and the Response from Asia, 52(6) Journal of WorLd Trade 946-966 (2018).

Nengye Liu, Book Reviews: International Economic Law - China, State Sovereignty and International Legal Order by Phil C.W. CHAN, 8(2) Asian Journal of INTERNATIONAL LAW 491-492 (2018).

James Ransdell, Institutional Innovation by the Asian Infrastructure Investment Bank, 9(1) Asian Journal of International LaW 125-152 (2018). 
John Riley, The Legal and Policy Implications of the US Steel Tariffs on East Asia, 11(1) Journal of EASt Asia ANd International LAW 193-204 (2018).

Anna G. Tevini, Regional Economic Integration and Dispute Settlement in East Asia: The Evolving Legal Framework (2018).

Sakda Thanitcul \& Amonwalai Ninpanich, Does Thailand Fulfill the ASEAN Requirements for Foreign Direct Investment under Partial Liberalization in Electricity Industry?, 11(2) JOURNAL OF EAST Asia AND INTERNATIONAL LAW 293-313 (2018).

Ernst-Ulrich Petersmann, International Economic Law Without Human and Constitutional Rights? Legal Methodology Questions for my Chinese Critics, 21(1) JoU RNAL OF INTERNATIONAL ECONOMIC LAW 213-231 (2018).

Yun Zhao (ed.), International Governance and the Rule of LaW in China Under the Belt And Road Initiative (2018).

\section{$8 \quad$ Intellectual Property and Technology}

Anupam Chander \& Madhavi Sunder, The Battle to Define Asia's Intellectual Property Law: From TPP to RCEP, 8(3) UC Irvine LAW REviEW 331-361 (2018).

Chia-Yi Liu et al., The Relationship Between Patent Attributes and Patent Litigation: Considering the Moderating Effects of Managerial Characteristics, 23(2) AsIA Pacific Management Review 121-129 (2018).

Michael Loney, The Latest IP Moves in the US, Europe, and Asia, Managing Intellectual Property (2018).

Michael Loney, The Week in IP - Federal Circuit's Converse Ruling, US Indicts China Entity for Trade Secret Theft, and More, Managing Intellectual Property (2018).

Abu Bakar Munir et al., Data Protection law in Asia (2d ed. 2018).

Kholis Roisah, Emloyee-Inventor's Right to Compensation in Patent Law System in Indonesia and Some Countries, IX 7(37) Journal of Advanced ReSEARCH IN LAW AND ECONOMICS 2415-2424 (2018).

Belinda Townsend et al., Japan's Emerging Role in the Global Pharmaceutical Intellectual Property Regime: A Tale of Two Trade Agreements, 21(1-2) THE Journal of World Intellectual Property 88-103 (2018).

Fan Yang \& Jian Xu, Privacy Concerns in China's Smart City Campaign: The Deficit of China's Cybersecurity Law, 5(3) Asia \& The Pacific Policy Studies 533-543 (2018).

Yang Yu, Is the US Method of Challenging China's IP-related Practices Legally Tenable from an International Legal Perspective?, 11(2) JoURnAL OF EAST ASIA AND INTERNATIONAL LAW 413-433 (2018). 


\section{Environmental Law}

Bridie Butterfield, The Potential Role of Climate Change Litigation in Furthering the Mitigation Objectives of the Paris Agreement, 21(1) Asia Pacific Journal of Environmental LAW 29-49 (2018).

Alan Chong \& Jun Yan Chang, The International Politics of Air Disasters: Lessons for Aviation Disaster Governance from Asia, 2014-2015, 31(3-4) CAMBRIDGE REview of International Affairs 249-271 (2018).

Andrés Bautista-Hernáez, A Comparative Study on International Disaster Law Applicable to Spain and the Philippines, 66(1) Estudios De Deusto: Revista De La Universidad De Deusto 235-252 (2018).

Seokwoo Lee \& Lowell Bautista, Part XII of the United Nations Convention of the Law of the Sea and the Duty to Mitigate Against Climate Change: Making Out a Claim, Causation, and Related Issues, 45(1) ECOLOGY LAW QUARTERLY 129-155 (2018).

Takako Morita \& Christina Pak, Legal Readiness to Attract Climate Finance: Towards a Low-Carbon Asia and Pacific, 12(1) CARbon \& Climate Law Review 6-14 (2018). Rafael M. Plaza, A Blue Energy Option for the Mekong River Basin. An International Law Analysis on Asian Regional Cooperation in Pioneer Osmotic Power Projects, 25 Sustainable Energy Technologies and Assessments 75-98 (2018).

Gabrielle Simm, Disaster Response in Southeast Asia:The ASEAN Agreement on Disaster Response and Emergency Management, 8(1) ASIAN JournAL Of INTERNATIONAL LAW 116-142 (2018).

Fanny Thornton, Climate Change and People on the Move: InterNATIONAL LAW AND Justice (1st ed. 2018).

Rehan Abeyratne, Ordinary Wrongs as Constitutional Rights: The Public Law Model of Torts in South Asia, 54(1) TeXas International LaW Journal 1-37 (2018).

Deepa Das Acevedo, Gods' homes, Men's Courts, Women's Rights, 16(2) InTE RnATIONAL Journal of Constitutional LaW 552-573 (2018).

Buhm-Suk Baek, Partially Right, Partially Wrong: Rethinking the Implementation of International Human Rights Law in Countries with Gross Human Rights Violations, 33(2) PACific Focus 352-375 (2018).

Mary Buckley, The Politics of Unfree labour in Russia: Human TrafFiCKING AND LABOUR Migration (2018).

Saltanat Childress \& Darald Hanusa, "All the System is Simply a Soap Bubble": Legal Help-Seeking for Domestic Violence Among Women in Kyrgyzstan, 33(2) JoU RNAL OF FAMILY VIOLENCE 147-16o (2018). 
M. Christian Green \& Monica Duffy Toft, Freedom of Religion or Belief Across the Commonwealth: Hard Cases, Diverse Approaches, 16(4) The Review of FAith \& International AfFairs 19-33 (2018).

Jamal Greene \& Madhav Khosla, Constitutional Rights in South Asia: Introduction, 16(2) International Journal of Constitutional LaW 470-474 (2018).

Abdul Hamid \& Zaleha Kamaruddin, International Parental Child Abduction in the Malaysian Legal Context: Addressing Issues and the Way Forward, 26(2) IIUM LAW JOURNAL 275-306 (2018).

Lalu Husni \& Ani Suryani, Legal Protection for Woman Domestic Workers Based on the International Convention, 21(2) JoURNAL OF LEGAL, ETHICAL, AND REGULATORY Issues 1-7 (2018).

Tauqeer Hussain, Pre-Trial Detention and its Compensation in International and Pakistani Law, 15(3) Policy Perspectives 47-66 (2018).

Pranoto Iskandar, Indigenizing Constitutionalism: A Critical Reading of "Asian Constitutionalism", 5(1) The Indonesian Journal of International \& Comparative Law: Socio-Political Perspectives 3-42 (2018).

Pranoto Iskandar, Non-Citizen Rights in ASEAN: The Need to Chart a New Course, 27(2) Social \& Legal Studies: An International Journal 180-199 (2018).

Ridoan Karim et al., Human Rights-Based Approach to Science, Technology and Development:A Legal Analysis, 11(1)Journal of EAST ASIA AND INTERNATIONAL LAW 163-181 (2018).

Mirjam Künkler, The Bureaucratization of Religion in Southeast Asia: Expanding or Restricting Religious Freedom?, 33(2) The JournaL OF LAW AND RELIGION 192196 (2018).

Tomas Larsson, Buddhist Bureaucracy and Religious Freedom in Thailand, 33(2) THE JoURNAL OF LAW AND RELIGION 197-211 (2018).

Flavia lattanzi \& Emanuela Pistoia (eds.), The Armenian Massacres of 1915-1916 A Hundred Years Later: Open Questions and Tentative ANSWERS In International LAW (2018).

Mara Malagodi, Challenges and Opportunities of Gender Equality Litigation in Nepal, 16(2) International Journal of Constitutional LAW 527-551(2018).

Deepak Mehta \& Rahul Roy (eds.), Violence and the Quest for Justice in South Asia (2018).

Jeaneé C. Miller et al., Accusatorial and Information-Gathering Interview and Interrogation Methods: A Multi-Country Comparison, 24(9) Psychology, Crime \& LAW 935-956 (2018).

Elizabeth Mills, Gender, Sexuality and the Limits of the Law, 8(3) Global DisCOURSE 473-484 (2018).

Fait Muedini, LGbTi Rights in Turkey: Sexuality and the State in the Middle EAst (2018). 
Yumiko Nakanishi (ed.), Contemporary Issues in Human Rights Law: Europe AND Asia (2018).

Joel E. Oestreich, Sexual Orientation and Gender Identity in Nepal: Rights Promotion Through UN Development Assistance, 17(2) Journal of Human Rights 265-279 (2018).

Pascale Hancart Petitet, Abortion Politics in Cambodia Social History, Local Forms and Transnational Issues, 13(6) Global Public Health: An International Journal for Research, Policy and Practice 692-701 (2018).

Azmi Sharom, Law and the Judiciary: Divides and Dissent in Malaysia, 7(3) Sout HEAST Asian Studies 391-413 (2018).

Rajnesh Singh, Mapping Online Child Safety in Asia and the Pacific, 5(3) Asia \& The Pacific Policy Studies 651-664(2018).

Edmond J. Smith, Reporting and Interpreting Legal Violence in Asia: The East India Company's Printed Accounts of Torture, 1603-24, 46(4) THE JOURNAL OF IMPERIAL And Commonwealth History 6o3-626 (2018).

Elizabeth Zuccala \& Richard Horton, Addressing the Unfinished Agenda on Sexual and Reproductive Health and Rights in the SDG Era, 391(10140) THE LANCET 2581-2583 (2018).

\section{Migration and Refugees}

Te-Yuan Chien, Differentiated Human Rights of Migrant Spouses Based on Nationalities in Taiwan, 19(2) Asia-Pacific Journal on Human Rig HTS AND THE LAW 81-112 (2018).

Mary Crock \& Lenni B. benson (eds.), Protecting Migrant Children: In Search of Best Practice (2018).

Bilal Dewansyah \& Irawati Handayani, Reconciling Refugee Protection and Sovereignty in ASEAN Member States: Law and Policy Related to Refugee in Indonesia, Malaysia and Thailand, 12(4) Central European Journal of International \& Security Studies 473-485 (2018).

Zuraini Ab Hamid et al., Rights of Migrant Workers under Malaysian Employment Law, 11(2) Journal of East Asia ANd International LAW 359-374 (2018).

Lauri Kai, Embracing the Chinese Exclusion Case: An International Law Approach to Racial Exclusions, 59(6) William AND MARY LAW REVIEW 2617-2662 (2018).

Ruchi Lal, Social and Economic Rights of Refugees Under International Legal Framework: An Appraisal, 58(3) Indian Journal of International LaW 467-488 (2018). Jera Lego, Making Refugees (Dis)Appear: Identifying Refugees and Asylum Seekers in Thailand and Malaysia, 11(2) Austrian Journal of Southeast Asian STUdiEs 183-198 (2018). 
Zezen Zaenal Mutaqin, The Rohingya Refugee Crisis and Human Rights: What Should ASEAN Do?, 19(1) Asia-Pacific Journal on Human Rights and the Law 1-26 (2018).

Natasha Raheja, Neither Here nor There: Pakistani Hindu Refugee Claims at the Interface of the International and South Asian Refugee Regimes, 31(3) JoU RNAL OF REFUGEE STUdiEs 334-352 (2018).

Christopher Rossi, The Nomos of Climate Change and the Sociological Refugee in a Sinking Century, 50(3) The George Washington International Law REVIEW 613-652 (2018).

Saskia Sassen, A Third Emergent Migrant Subject Unrecognized in Law: Refugees From 'Development' (2018).

Executive Committee of the High Commissioner's Programme, Note on International Protection, 3o(1) International Journal of Refugee LaW 140-159 (2018).

\section{International Humanitarian Law, Criminal Law, and Transnational Crime}

Rebecca Barber, Legal Preparedness for the Facilitation of International Humanitarian Assistance in the Aftermath of Vanuatu's Cyclone Pam, 8(1) Asian Journal of INTERNATIONAL LAW 143-165 (2018).

Bonhoefer Bernardez, Book Reviews: International Criminal Law - Trials for International Crimes in Asia by Kirsten Sellars, 8(1) Asian Journal of InternaTIONAL LAW 295-296 (2018).

W.L. Cheah \& Moritz Vormbaum, British War Crimes Trials in Europe and Asia, 1945-1949: A Comparative Study, 31(3) Leiden Journal of International LaW 669-692 (2018).

David Cohen \& Yuma Totani, The Tokyo War Crimes Tribunal: Law, History, AND JURISPRUdENCE (2018).

Mark D. Kielsgard \& Tam Hey Juan Julian, Autocatalytic Models of Counter-Terrorism in East and Southeast Asia: An International Comparative Analysis of China, Indonesia, and Thailand, $5 \mathrm{O}(3)$ The George Washington International LaW Review 461-522 (2018).

Jingyuan Ma \& Mel Marquis, Moral Wrongfulness and Cartel Criminalization in East Asia, 35(3) Arizona Journal of International and Comparative LAW 377-434 (2018).

Xiao Mao, Substantive or Jurisdictional? The Tokyo Charter and the Legality Challenge at the International Military Tribunal for the Far East, 11(2) JoU RNAL OF EAST As IA AND INTERNATIONAL LAW 435-451 (2018). 
Melinda Rankin, Australia's Responsibility to Prosecute? Bridging the Gap of International Criminal Law in Syria and Iraq, 72(4) Australian Journal of INTERNATIONAL AFFAIRS 322-328 (2018).

Will smiley, From Slaves to Prisoners of War: The Ottoman Empire, Russia, ANd International LAW (2018).

A.K. Syahmin \& Fidelia Fidelia, The International Cooperation to Eradicate Illicit Firearms Trafficking in Southeast Asian Region, 2(2) SRIWIJAYA LAW REVIEW 183192 (2018).

Emma van Santen, Combatting Organized Crime and Terrorism in Central Asia, 25(2) Journal of Financial Crime 3o9-319 (2018).

Kerstin von Lingen (ed.), Transcultural Justice at the Tokyo Tribunal: The Allied Struggle for Justice, 1946-48 (2018).

Andrew Wolman, Humanitarian Protection Advocacy in East Asia: Charting a Path Forward, 37(1) Refuge Survey QuARTERLy 25-43 (2018).

\section{Law of the Sea}

Abdullah Al Arif, Legal Status of the Precautionary Principle in International Fisheries Law and its Application in the Marine Fisheries Regime of Bangladesh, 3(1) AsIAPacific Journal of Ocean LaW AND Policy 95-114 (2018).

Tara Davenport, Island-Building in the South China Sea:Legality and Limits, 8(1) As IAN JoURNAL OF INTERNATIONAL LAW 76-9o (2018).

Bruce A. Elleman, China's Naval Operations in the South China Sea: Evaluating Legal, Strategic and Military Factors (2018).

Huiyun Feng \& Kai He (eds.), us-china Competition and the South China Sea Disputes (2018).

Douglas Guilfoyle, The South China Sea Award: How Should We Read the UN Convention on the Law of the Sea?, 8(1) As IAn Journal of International LaW 51-63 (2018). Paul Hallwood \& Thomas Miceli, Piracy and Privateers in the Golden Age: Lessons for Today, 49(3) Ocean Development and International Law 236-246 (2018). Nong Hong, The South China Sea Arbitration: A Test for the Efficacy of Compulsory Mechanism of UNCLOS and Implications for Dispute Management in the Region, 10(2) Asian Politics \& Policy 219-246 (2018).

Hyun Jung Kim, Governing Fishing Stocks in Northeast Asia's Disputed Waters: Preventing a 'Tragedy of the Commons'?, 33(3) The International Journal of Marine AND COASTAL LAW 495-527 (2018).

Nehginpao Kipgen, ASEAN and China in the South China Sea Disputes, 49(3) AsIan AFFAIRS 433-448 (2018). 
Kei Koga, Japan's Strategic Interests in the South China Sea: Beyond the Horizon?, 72(1) Australian Journal of International Affairs 16-3o (2018).

Whiejin Lee, The Law of the Sea Regime in Northeast Asia: Issues and the Way Forward, 32(1) The Journal of East Asian Affairs 45-70 (2018).

Xinmin Ma, Merits Award Relating to Historic Rights in the South China Sea Arbitration: An Appraisal, 8(1) Asian Journal of International LaW 12-23 (2018).

Wim Muller, Book Reviews: Law of the Sea-Recent Developments in the South China Sea Dispute: The Prospects of a Joint Development Regime edited by Wu Shicun and Nong Hong, The South China Sea Disputes and Law of the Sea edited by S.JAYAKumar, Tommy Кон, and Robert Bec KMan, The South China Sea Arbitration: A Chinese Perspective edited by Stefan TALmon and Bing Bing, The ChinaJapan Border Dispute: Islands of Contention in Multidisciplinary Perspective edited by Tim F. Liao, Kimie Hara, and Krista Wiegand, Arbitration Concerning the South China Sea: Philippines Versus China edited by WU Shicun and Keyuan ZoU, 8(1) Asian Journal of International LAW 296-299 (2018).

Christine Sim, Book Reviews: Law of the Sea - Unresolved Border, Land and Maritime Disputes in Southeast Asia: Bi- and Multilateral Conflict Resolution Approaches and ASEAN's Centrality edited by Alfred Ge rstl and Maria Strasakova, 8(2) Asian JOURNAL OF INTERNATIONAL LAW 495-496 (2018).

Jonathan Spangler et al. (eds.), Enterprises, localities, People, and Policy in the South China Sea: Beneath the Surface (2018).

Peter Vandergeest, Law and Lawlessness in Industrial Fishing: Frontiers in Regulation Labour Relations in Asia, 68 (229-230) International Social Science JoURNAL 325-341 (2018).

Keyuan Zou (ed.), global Commons and the Law of The Sea (2018).

\section{Maritime Law}

Jesse Greene, The Glenn Defense Marine Asia Problem: The Role of Ethics in Procurement Reform, 48(1) Public Contract LaW Journal, 16-34 (2018).

Gordon Houlden \& Nong Hong (eds.), Maritime Order and the LaW in EASt Asia (2018).

Abul Kalam, Bangladesh's Maritime Policy: Entwining Challenges (2018).

Suk Kyoon Kim, The Expansion of and Changes to the National Coast Guards in East Asia, 49(4) Ocean Development \& International LaW 313-334 (2018).

Seokwoo Lee \& Eonkyung Park, Maritime Law Enforcement by the Republic of Korea Concerning Proliferation of Weapons of Mass Destruction: Search and Interdiction, 33(3) Pacific Focus 478-496 (2018). 
Jinxing Ma, A Chinese Perspective of Treaty Interpretation on the Status of Maritime Features: In Response to the South China Sea Arbitration Award, 11(1) Journal of East Asia and International LaW 99-120 (2018).

Brian McGarry, The Settlement of Maritime Boundary Disputes in Southeast Asia and Oceania: A Synthesis in Light of Indonesian Practice, 5(2) JOURNAL OF TERRITORIAL ANd Maritime Studies 24-45 (2018).

Giacomo Morabito \& Bruno Sergi, How did Maritime Piracy Affect Trade in Southeast Asia?, 18(2) Journal of East Asian Studies 255-265 (2018).

Rebecca Strating, Maritime Territorialization, UNCLOS and the Timor Sea Dispute, 4O(1) Contemporary Southeast Asia 101-125 (2018).

Chonghei Zheng et al., 21St Century Maritime Silk Road: A Peaceful WAY FORWARD (2018).

\section{Watercourses}

Maxat Kassen, Understanding Foreign Policy Strategies of Kazakhstan: a Case Study of the Landlocked and Transcontinental Country, 31(3-4) CAMBridge REview of International AfFAirs 314-343 (2018).

Salman M.A. Salman \& Kishor Uprety, Shared Watercourses and Water Security in South Asia: Challenges of Negotiating and Enforcing Treaties, 3(3) BRILL RESEARCH Perspectives in International Water LaW 1-10o (2018).

Nilant hi Samaranayake et Al., Raging Waters: China, India, Bangladesh, and Brahmaputra River Politics (2018).

Patricia Wouters et al. (eds.), Transboundary Water Cooperation: Principles, Practice and Prospects for China and its Neighbours (2018).

Aibek Zhupankhan et al., Water in Kazakhstan, a key in Central Asian Water Management, 63(5) Hydrological Sciences Journal 752-762 (2018).

Aigerim Zhunusbekova et al., International Legal Aspects of Regulating the Use of Transboundary Rivers in Central Asia, 9(5(35)) Journal of AdVANCED RESEARCH IN LAW AND ECONOMICS 1856-1862 (2018).

\section{$16 \quad$ Air and Space}

Armand De Mestral et al. (eds.), Sustainable Development, International Aviation, and Treaty Implementation (2018).

Shengli Jiang \& Yun Zhao, The Aftermath of the US Space Resource Exploration and Utilization Act: What's Left for China?, 11(1) Journal of EAst AsIA AND INTERNATIONAL LAW 9-34 (2018). 
Han Taek Kim, Fundamental Principles of Space Resources Exploitation: A Recent Development of International and Municipal Law, 11(1) Journal of EAst Asia AND InTERnATIONAL LAW 35-52 (2018).

Sinead Spencer, The Demand for a Single International Search and Rescue Agreement Template Flexible for Mutl-regional Use as Disseminated by the International Civil Aviation Organisation, 3 Perth International Law Journal 115-157 (2018).

Amad Sudiro, Regulating Ballistic Missile Usage for Ensuring Civil Aviation Safety: As a Matter of Urgency, 11(2) Journal of EAST Asia AND International LAW 453464 (2018).

\section{Miscellaneous}

Itty Abraham, Decolonizing Arms Control: the Asian African Legal Consultative Committee and the Legality of Nuclear Testing, 1960-1964, 26(3) Asian JournaL of Political SCIENCE 314-33o (2018).

Muralee Das, International Regulation of Fantasy Sports: Comparative Legal Analysis of United States, Australian, and Asian Laws, 8(2) UN LV GAMIN G LAW Jou RNAL 93-120 (2018).

Nader Entessar \& Kaveh l. Afrasiabi, Iran Nuclear Accord and the Remaking of the Middle East (2018).

Stewart Fenwick, Eat, Pray, Regulate: The Indonesian Ulama Council and the Management of Islamic Affairs, 33(2) JouRNAL OF LAW AND RELIGION 271-29o (2018).

Jae Woon Lee, Book Reviews: Other Areas of International Law - A Level Playing Field for "Open Skies": The Need for Consistent Aviation Regulation by Peter Paul Fitzgerald, 8(1) Asian Journal of International LaW 300 (2018).

Erik Mobrand, Limited Pluralism in Liberal Democracy: Party Law and Political Incorporation in South Korea, 48(4) Journal of Contem Porary Asia 6o5-621 (2018).

Hong Thao Nguyen, Asia-Pacific Moving Towards the Ratification of the Treaty on the Prohibition of Nuclear Weapons, 11(2) Journal of EAST Asia AND InTERNATIONAL LAW 465-475 (2018).

K. Nick, International Nuclear Law Essentials in Singapore, 35(2) NEA NEWS 19 (2018). Saumya Saxena, Commissions, Committees, and Custodians of Muslim Personal Law in Postindependence India, 38(3) Comparative Studies of South Asia, Africa, AND THE Middle EAST 423-438 (2018).

Lee Edson Yarcia \& Allan Chester Nadate, Redesigning Government Regulations Towards a Tobacco Endgame Strategy: A Comparative Law Approach, 16(1) Товассо INDUCED DisEASES 37 (2018).

Ting-Fai Yu, Contextualising the National Anthem Law in Mainland China and Hong Kong:Football as a Field of Political Contention, 2018(3) China PerspeCtives 79-82 (2018). 